Food, Dairy and Home Economic Research

\title{
EFFECT OF RUSK CONTAINING SOME PLANT OILS ON HYPERCHOLESTEROLEMIC RATS
}

\author{
Fatma S-El. Ismail", Madiha A. El-Shewey, Hanan S. Shalaby and Dalia A. Zaki \\ Food Sci. Dept., Fac. Agric., (Rural Home Econ.), Zagazig Univ., Egypt
}

Received: 30/04/2019; Accepted: 29/05/2019

\begin{abstract}
Plant oils as sunflower, sesame and fenugreek oils has been successfully used in food technology. They have multi purpose for human health as safe and natural additives. Thus, this research was carried out to study the fatty acids composition of sunflower, sesame and fenugreek oils. Chemical composition and sensory evaluation of rusk containing these plant oils were studied. Also, Thirty-six male rats were divided into 6 groups to study the effect of feeding hypercholesterolemic rats, on rusk containing these plant oils, for six weeks on lipid profile, kidney functions, liver functions and histopathological examination of liver. The results showed that fenugreek oil had the highest total unsaturated fatty acids $86.19 \%$ followed by sesame and sunflower oils revealing $85.05 \%$ and $81.86 \%$, respectively. Rusk product manufactured from studied oils at ratio 1:1:1 W:W:W(T3) had the highest content of moisture, crude protein, fat and ash. While, it had the lowest content of carbohydrate. Moreover, as a result of feeding hypercholesterolemic rats on rusk products fortified with plant oils caused a significant decrease in Triglyceride (TG), Total cholesterol (TC), Low density lipoprotein (LDL), Very low density lipoprotein (VLDL), LDL/HDL ratio and a significant increase in High density lipoprotein (HDL) after 6 weeks of feeding compared to the positive control group. The results indicated that liver enzymes and kidney functions of hypercholesterolemic rats were improved significantly as a result of feeding on rusk products. So, the group feeding on rusk product fortified with mixture of sunflower, sesame and fenugreek oils at ratio 1:1:1 W:W:W(T3) had the lowest levels of all these parameters compared to the positive control group. It could be recommended that adding plant oils as sunflower, sesame, fenugreek oils at ratio $1: 1: 1 \mathrm{~W}: W: W$ during the manufacture of Egyptian bakery (rusk) product can improve the health and nutritional benefits of this product and also, have positive effects on hypercholesterolemia.
\end{abstract}

Key words: Rusk, fatty acids, hypercholesterolemic, liver and kidney functions, lipid profile and histopathological examination.

\section{INTRODUCTION}

Plant oils have a great importance in food technology which affect the quality of products from a nutritional and functional perspective (Hedjazi et al., 2011). Cardiovascular diseases cause the highest percentage of death in human beings and there is a relation between development of cardiovascular diseases and lipid metabolism which are affected by diet, especially the quantity and types of fatty acids. $\alpha$-Linolenic acid and linoleic acid in oils may prevent

\footnotetext{
*Corresponding author: Tel. : +201026107855

E-mail address: fatma.elmesllamy@gmail.com
}

coronary heart diseases, hypertension and reduce cholesterol levels (Simopoulos, 2011).

Sunflower seeds oil (Helianthus annuus) is a source of unsaturated fatty acids and fat soluble vitamins. Sunflower oil is rich in linoleic acid, which is an essential n-6 polyunsaturated fatty acid. The biological effects of the n-6 fatty acids are mediated by their conversion to $n-6$ eicosanoids, n- 6 prostaglandins and leukotrienes, which are hormones that act at different levels in human metabolism, especially on the inflammatory response (Simopoulos, 2002). So, the intake of 
polyunsaturated fatty acids has a great effect on levels of lipoprotein cholesterol in the body, which play an important effect on the incidence of cardiovascular disease (Erkkilä et al., 2008). Sesame seed oil (Sesamum indicum L.) is extracted by pressing roasted seeds without further refining. Chinese, Korean and Japanese are using it in cooking because of its pleasant nutty flavour and a long shelf life and can be blended with others oils to improve their stability and shelf life. Moreover, it is highly resistant to oxidation and plays several medicinal effects (Kochhar, 2000). Fenugreek (Trigonellafoenum graecum) is belong to the leguminous family and considered as medicinal herbs which used for more than 2500 years due to its food and medicinal properties. It is reported to be native to West Africa but now cultivated in Asia and Latin America (Jiang et al., 2007; Shi et al., 2017). The seeds and leaves have a healthy beneficial purposes as anti-diabetic (Bahmani et al., 2016), anti-microbial (Subhapriya and Gomathipriya, 2018), anti-inflammation (Tavakoly et al., 2018), anti-cancer (El Bairi et al., 2017). Fenugreek seed oil is rich in omega-6 fatty acids (linoleic acid), which plays an important role in prevention of coronary heart diseases, inflammation and cancer (Akbari et al., 2018). Fenugreek essential oil from the seeds play an important role in the control of cholesterol metabolism (Strómgaard and Nakanishi, 2004; Tigrine-Kordjani et al., 2011).

Hypercholesterolemia is a risk factor for the development and progression of atherosclerosis and cardiovascular diseases. A high cholesterol diet is a major environmental contributor to unbalanced lipid metabolism and associated with an increase in prevalence of coronary heart disease (Libby, 2008). WHO (2008) reported that, cardiovascular disease (CVD) causes a major risk to worldwide deaths, from 17.1 million in 2004 to 23.4 million in 2030. CVD develops slowly due to long-term exposure to change in life style such as cigarette smoking, lack of exercise, constant stress, overweight and consuming diet with high saturated fat contents (Yokoyama et al., 2008; Neylon et al., 2013). So, Gustafsson et al. (1994) demonstrated that dietary oils has good effect on lipid peroxidation, which lead to favourable changes in the lipid status for hyperlipidemic patients.
Functional foods, the most natural and safest source of health ingredients which providing health benefits beyond basic nutrition and becoming popular in use for reducing the risk of CVDs (Han et al., 2018). Recently, unsaturated fatty acids are considered as functional ingredients and nutraceuticals which it has antiatherogenic, antithrombotic, anti-inflammatory, antiarrhytmic, and hypolipidemic effect resulting in cardioprotective. Also, reducing the risk of serious diseases like cancer, osteoporosis, diabetes and other health promotion activities following from their complex influence on concentrations of lipoproteins, fluidity of biological membranes (Mišurcová et al., 2011; Mobraten et al., 2013). Rusk is a type of bakery product attributed with prolonged shelf-life beneficial in certain diets. Rusk is traditional hard in South Africans they love to dunk it in tea or coffee in the morning. (Fliiopovic et al., 1991). So, the aim of this work was to study the fatty acids composition of sunflower, sesame and fenugreek oils, chemical composition and sensory evaluation of Egyptian bakery product (rusk) fortified with tested plant oils. The effect of feeding hypercholesterolemic rats on rusk products fortified with tested plants oils on lipid profile, liver and kidney functions were studied.

\section{MATERIALS AND METHODS}

\section{Materials}

Sesame oil (Sesamum indicum L.) and fenugreek oil (Trigonella foenum-graecum) were purchased from El-Captain Company (CAP PHARM) Al-Obour city, Kalubia Governorate, Egypt. While, sunflower oil (Helianthus annuиs), wheat flour (72\% extraction), sugar powder, baker's yeast, salt, corn oil, and starch were purchased from the local market at Zagazig city, Sharkia Governorate, Egypt.

Adult thirty six male albino rats, weighing 110-120 g, were purchased from breeding unit of Helwan Experimental Station.

Cholesterol powder and kits (total cholesterol, triglyceride and total high -density lipoprotein cholesterol (HDL-C), total protein, ALT, AST, 
creatinine and urea) were purchased from Sigma-Aldrich (MO, IL USA). Reagents and chemicals used were of the highest purity.

\section{Methods}

\section{Chemical Analyses}

\section{Fatty acids composition of plant oils}

Saponification and esterification of different oils were performed according to Hartman and Lago (1973) and then analyzed by gas chromatography according to AOAC (2005). The instrument used was HP6890 with flam ionization detector. Column was DB-23, 30m, $0.32 \mathrm{~mm}$ ID and $0.25 \mu \mathrm{m}$ film thickness. Identification of the peaks was carried out by their retention time.

\section{Preparation of rusk}

Local Egyptian bakery product (rusk) were prepared by mixing all dry ingredients, $100 \mathrm{~g}$ of white flour with $0.5 \%$ baker's yeast, $1 \%$ salt, $30 \%$ sunflower oil and water as needed dough in a mixer ( Ka 5ss, Kitchen Aid, st. Joseph, mt) at speed 2 at room temperature for $3 \mathrm{~min}$. The dough was mixed well for about $2 \mathrm{~min}$ at speed 2 and another $1 \mathrm{~min}$ at speed 4 , then the dough was covered by plastic sheet and allowed to rest for 5 min at room temperature. After that, the dough was cut manually to small round pieces. The dough cut in pieces $9 \mathrm{~cm}$ thickness. Control sample (C) rusk containing 30\% sunflower oil, (T1) rusk containing 30\% sesame oil, (T2) rusk containing $30 \%$ fenugreek oil, (T3) rusk containing sunflower, sesame and fenugreek oils at ratio $1: 1: 1 W: W: W$. The dough was mixed well for about $5 \mathrm{~min}$ in mixer and was baked in the oven at $200^{\circ} \mathrm{C}$, approximately for $10 \mathrm{~min}$, until light brown colour according to standard AACC (2002) baking procedure. After cooling at ambient temperature, it was packed in lowdensity polyethylene bags until it was used for the analysis according to Filipovic et al. (2012).

\section{Chemical composition of rusk}

Moisture, crude protein, fat, and ash contents of rusk fortified plant oils were determined by the standard procedures described in the AOAC (2005). Total carbohydrates were calculated by difference according to the following equation:
Total carbohydrates $=100-[$ moisture $(\%)+$ crude protein $(\%)+$ crude fat $(\%)+\operatorname{ash}(\%)]$.

\section{Sensory evaluation for rusk}

The sensory evaluation of rusk fortified with plant oils was done to determine the acceptability of the product. Rusk was evaluated for (appearance, colour, flavour, taste, texture and over all acceptability) by 15 panelists from the staff members of Food Science Department, Faculty of Agriculture, Zagazig University according to Olaoye and Onilude (2008). The hedonic scale has 9 levels: the first four levels (1-4) show the positive sensations and the last four (6-9) show the negative sensations. The results are statistically analysed using multiple correspondence analyses.

\section{Biological Experiment}

\section{Experimental animals}

Thirty six healthy adult male albino rats weighting between 110-120 g, were housed in institutional experimental animal laboratory in Biochemistry Department, Faculty of Agriculture, Zagazig University, Egypt. The rats were kept in cages at room temperature. The rats were housed in stainless steel cages with screen bottom in a controlled environment with $12 \mathrm{hr}$., light and 12 hr., dark cycles. Water was available over period.

\section{Experimental design}

The rats were randomly classified into two main groups as follows: the $1^{\text {st }}$ group contain 6 rats as the negative control group G1(-Ve) and fed on basal diet which prepared according to Ain (1993) along the period of experimental. The $2^{\text {nd }}$ group (30 rats) were fed on high cholesterol diet which contain $(5 \%$ animal fat + $1 \%$ cholestrol $+0.25 \%$ colic acid) for two weeks to induce hybercholesterdimia for rats. Then, hypercholesterolemic rats were divided into 5 groups (6 rats for each) as follows:

Group 1: $(-\mathrm{Ve})$ the negative control group fed on basal diet.

Group 2: $(+\mathrm{Ve})$ the positive control group (hypercholesterolemic rats) which fed on basal diet only. 
Group 3: hypercholesterdimic group fed on rusk containing 30\% sunflower oil (control rusk).

Group 4: hypercholesterdimic group fed on rusk containing $30 \%$ sesame oil.

Group5: hypercholesterdimic group fed on rusk containing 30\% fenugreek oil.

Group6 (G6): hypercholesterdimia group fed on rusk containing mixture of sunflower, sesame and fenugreek oils at ratio 1: $1: 1 \mathrm{~W}: W: W$. diet.

The rusk products were added by $5 \%$ of basal

\section{Blood sampling and biochemical analysis}

The rats were killed after overnight fasting. Blood samples were collected from the eye plexuses under diethyl ether anesthesia after 3 , and 6 weeks from the start. The samples were collected in tubes $5 \mathrm{ml}$ syringe by cardiac puncture and were centrifuged at $3000 \mathrm{rpm}$ for $15 \mathrm{~min}$ to separate serum. The triglyceride was analyzed according to Young (2001), total cholesterol was analyzed according to Burtis (1999), HDL-Cholesterol was measured by enzymatic colorimetric method using Randox kits (Tietz, 1995). LDL-Cholesterol and VLDLcholesterol were calculated by using the method of Friedewald $\boldsymbol{e t}$ al. (1972) as follows: VLDL$\mathrm{C}=$ Triglycerides $/ 5$.

\section{LDL-C $=$ Total cholesterol- $($ HDL-C+VLDL-C $)$}

The liver enzymes activities, alanine amino transferase (ALT), aspartate amino transferase (AST) and total protein were determined using kits (Young, 2001). Kidney functions was determined as serum creatinine and blood urea nitrogen by enzymatic colorimetric methods using commercial kits sigma-Aldrich (Young, 2001).

\section{Histopathological Examination}

Liver of the rat was taken immediately after sacrificing the rats and immersed in $10 \%$ buffered neutral formalin solution, the fixed specimens then trimmed, washed and dehydrated in bedded, in paraffin cut into sections of 4-6 microns thickness and stained with haematoxylin and Cosin stain according to Suvarna et al. (2013). Histopathological studies were monitored by microscopic examination of paraffin embedded slices of liver from rats. All sections are examined at 400X magnification using a light microscope in Faculty of Veterinary, Zagazig University, Egypt.

\section{Statistical Analysis}

The obtained results were statistically tested by analysis of multi variance ANOVA and discriminative test. ANOVA functions and Roy test both with 0.05 significance level were used as Unitarian statistical procedures to assess significant differences among means (Steel and Torrie, 1980).

\section{RESULTS AND DISCUSSION}

\section{Fatty acids Composition of Plant Oils (\%)}

Fatty acids composition of sunflower, sesame and fenugreek oils are shown in Table 1. Results indicated that sunflower oil had the highest total saturated fatty acids $18.14 \%$ of total fatty acid. Whereas, fenugreek oil and sesame oil had the highest total unsaturated fatty acid amounted to be 86.19 and $85.05 \%$, respectively. Sunflower oil had a high concentration of linoleic acid (54\%), moderate amount of oleic acid (26.19\%) and low amount of stearic acid (8.42\%), palmitic acid $(9.16 \%)$, arachidic acid $(0.33 \%)$ and behenic acid $(0.23 \%)$. Meanwhile, linolenic acid $(0.62 \%)$, vaccinic acid $(0.60 \%)$, gadolic acid $(0.23 \%)$, alpha octadecatetraenoic $(0.11 \%)$, and eicosaenoic acid $(0.11 \%)$ were found in very low concentration. Salas et al. (2011) reported that sunflower oil contain, palmitic acid (5.0\%), stearic acid $(6.5 \%)$, oleic acid (36.6\%), linoleic acid $(51.0 \%)$, arachidic acid $(0.3 \%)$ and behenic acid (0.6\%). Arshad and Amjad (2012) showed that, sunflower oils have a negligible amount of saturated fatty acid (SFA), but more amount of linoleic acid and oleic acid. Budryn et al. (2014) revealed that, fatty acids composition for sunflower oil were $5.71 \%$ palmitic acid, $3.34 \%$ stearic acid, $24.06 \%$ oleic acid, $64.97 \%$ linoleic acid, $0.09 \%$ linolenic acid, $0.22 \%$ arachidic acid, $0.17 \%$ eicosaenoic acid and $0.75 \%$ behenic acid. Orsavova et al. (2015) found that, sunflower oil contain palmitic acid $6.2 \%$, stearic acid $2.8 \%$, oleic acid $28.0 \%$, linoleic acid $62.2 \%$, linolenic acid $0.16 \%$, arachidic acid $0.21 \%$ and gadolic acid $0.18 \%$. 
Table 1. Composition of fatty acids in plant oils $(\%)$

\begin{tabular}{|c|c|c|c|}
\hline Fatty acid & Sunflower oil & Sesame oil & Fenugreek oil \\
\hline Palmitic acid C16:0 & 9.16 & 9.11 & 8.54 \\
\hline Palmitolic acid C16:1 & $\mathrm{ND}^{*}$ & 0.15 & 0.12 \\
\hline Stearic acid C18:0 & 8.42 & 5.15 & 4.48 \\
\hline Vaccinic acid C18:1 & 0.60 & 0.94 & 0.94 \\
\hline Oleic acid C18:1 09 & 26.19 & 42.92 & 37.11 \\
\hline Linoleic acid C18:2 $\omega 6$ & 54.00 & 39.70 & 45.40 \\
\hline Linolenic acid C18:3 $\omega 3$ & 0.62 & 0.95 & 2.39 \\
\hline Alpha octadecatetra enoic acid C18:4 $\omega 3$ & 0.11 & $\mathrm{ND}^{*}$ & $\mathrm{ND}^{*}$ \\
\hline Arachidic acid C20:0 & 0.33 & 0.69 & 0.64 \\
\hline Eicosa enoic acid C20:1 $\omega 11$ & 0.11 & $\mathrm{ND}^{*}$ & $\mathrm{ND}^{*}$ \\
\hline Gadolic acid C20:1 $\omega 9$ & 0.23 & 0.39 & 0.23 \\
\hline Behenic acid C22:0 & 0.23 & $\mathrm{ND}^{*}$ & 0.15 \\
\hline Saturated fatty acids & 18.14 & 14.95 & 13.81 \\
\hline Unsaturated fatty acids & 81.86 & 85.05 & 86.19 \\
\hline
\end{tabular}

ND*: Not detected

Also, fatty acids content for sesame oil are cleared in the same Table which the oleic acid $(42.92 \%)$ was the major fatty acid found in sesame oil followed by linoleic acid $(39.70 \%)$. palmitic acid $(9.11 \%)$, stearic acid (5.15) and arachidic acid $(0.69 \%)$. Meanwhile, linolenic acid $(0.95 \%)$, vaccinic acid $(0.94 \%)$, gadolic acid $(0.39 \%)$ and palmitolic acid $(0.15 \%)$ were found in very small concentrations. Ahmad et al. (2006) indicated that, myristic acid $(0.61 \%)$, palmitic acid (12.3\%), stearic acid (3.9\%), oleic acid $(43.2 \%)$, linoleic acid $(42.6 \%)$, linolenic acid $(0.27 \%)$ and arachidic acid $(0.23 \%)$ were detected in sesame oil. Moreover, Sowmya et al. (2009) reported that, sesame oil was contained palmitic acid (10.8\%), stearic acid $(5.7 \%)$, oleic acid $(43.0 \%)$ and linoleic acid (40.1\%). Also, Orsavova et al. (2015) estimated that, sesame oil contain palmitic acid (9.7\%), palmitolic acid $(0.11 \%)$, stearic acid $(6.5 \%)$, oleic acid (41.5\%), linoleic acid (40.9\%), linolenic acid $(0.21 \%)$, arachidic acid $(0.63 \%)$ and gadolic acid $(0.32 \%)$.
Concerning fenugreek oil, it is characterised by a high concentration of linoleic acid (45.4\%), moderate level of oleic acid $(37.11 \%)$, low levels of palmitic acid, stearic acid, arachidic acid and behenic acid to be $8.54 \%, 4.48 \%$, $0.64 \%$ and $0.15 \%$, respectively. While, linolenic acid $(2.39 \%)$, vaccinic acid $(0.94 \%)$, gadolic acid $(0.23 \%)$ and palmitolic acid $(0.12)$ were found in a small concentrations. Fatty acids concentration of fenugreek oil were affected by genetic factors and environmental conditions during fruit development and maturity (Egan $\boldsymbol{e t}$ al., 1981). Ziwar (2010) found that Fenugreek oil contain high amount of unsaturated fatty acid $(83 \%)$, linoleic acid recorded the highest percentage $(47 \%)$ followed by oleic acid $(36 \%)$. While, total saturated fatty acids was $17 \%$ which contain palmitic acid (11\%) and steric acid (6\%). Also, Ali et al. (2012) reported that fenugreek oil contained high amount of linoleic acid $(42.5 \%)$. While, linolenic acid, oleic acid and palmitic acid contents were found to be 18 , 20 and $10.5 \%$, respectively. Also, the oil contained small amounts of stearic acid (6.5\%) and arachidic acid (2\%). 


\section{Chemical Composition of Rusk contaning Different Ratio of Plant Oils}

Table 2 shows the proximate chemical composition of rusk prepared from plant oils (sunflower oil, fenugreek oil and sesame oil). It is observed that, rusk containing a mixture of sunflower, sesame and fenugreek oils (T3) had the highest content of moisture (2.58\%) followed by control sample (C) $2.49 \%$ and (T1) $2.31 \%$. Also, rusk containing a mixture of sunflower oil ,sesame oil and fenugreek oil (T3) had the highest content of protein to be $9.6 \%$ followed by T2, T1 and control rusk product to be $8.6,8.4$ and $7.9 \%$, respectively. Moreover, T3 and T2 had the highest content of crud fat and ash to be (26 and 28\%) and (1.30 and $0.81 \%$ ) for fat and ash, respectively. While, control rusk (C) and rusk product containing $30 \%$ sesame oil (T1) had the lowest content of crud fat and ash (22,0.55\%), respectively. On the other hand, control rusk (C), had high content of carbohydrates $67.06 \%$, followed by $\mathrm{T} 166.65 \%$. While, T2 and T3 had the lowest content to be 60.45 , and $60.52 \%$, respectively.

It could be concluded that, rusk product containing a mixture of plant oils (T3) had the highest content of moisture, crude protein, fat and ash. While, it had the lowest content of carbohydrate. Meanwhile, the control rusk had the highest content of carbohydrate and the lowest contents of crude protein, crude fat and ash.

Ingale and Shrivastava (2011) indicated that sunflower seed contained $4.61 \%$ moisture, $36.85 \%$ fat, $25.08 \%$ crude protein, $27.76 \%$ carbohydrateand $4.82 \%$ ash. Zebib et al. (2015) revealed that the chemical composition of sesame (Egyptian varieties) contained 2.96\% moisture, $52.7 \%$ crude oil, $26.23 \%$ crude proteins, $9.77 \%$ carbohydrate, and $5.83 \%$ ash. Also, Mijena (2017) found that the chemical composition of hulled sesame seeds contained $2.27 \%$ moisture, $52.22 \%$ crude fat, $27.0 \%$ crude proteins, $15.11 \%$ carbohydrate, and $3.4 \%$ ash. However, some differences in the composition may be due to environmental stress, climatic conditions, geographical, cultivation and harvesting practices. Naidu et al. (2011) found that sesame (Egyptian varieties) contain 11.44\% moisture, $6.71 \%$ fat, $27.57 \%$ crude proteins, and $3.9 \%$ ash. The obtained results agree with Gupta, et al. (2011). Shalaby et al. (2016) showed that rusk products contain $28.05 \%$ fat, $0.55 \%$ ash and $11.30 \%$ crude proteins. But Almasodi (2018) found that control rusk products contained $3.80 \%$ moisture, $3.52 \%$ fat, $11.30 \%$ crude proteins and $83.81 \%$ carbohydrate and $0.55 \%$ ash.

\section{Sensory Evaluation of Rusk contaning Plant Oils}

The sensory evaluation of food products play an important role in food choices. Hedonic testing is often used to determine consumers attitude towards the food by measuring a degree of acceptance of a new product or improving the existing food product (Meilgard et al., 1991; Poster, 1991).

Sensory evaluation of rusk which contain different types and levels of oils are presented in Table 3. The results revealed that, there were significant differences $(\mathrm{p} \leq 0.05)$ in all sensory properties (appearance, colour, flavour, taste, texture and overall acceptability) of rusk samples compared with the control rusk sample (C). There were insignificant differences for colour score between control sample (C) and others rusk samples. On the other hand, there were a significant differences $(p \leq 0.05)$ between control rusk sample and others samples for flavour, taste and texture which containing different ratio and types of tested oils caused a significant decrease. Generally, it could be concluded that, the rusk produced by particular replacement of sunflower oil with mixture of sunflower, sesame and fenugreek oils (T3) gave rusk more acceptable appearance, colour, flavour, taste, texture and acceptability (8.11, $7.91,7.66,7.54,8.0$ and 7.66), respectively rather than the rusk produced by added other ratio and type of oils. Decreasing the fat content or substituting fat with different components has a huge influence on the texture characteristics of biscuits (Zoulias et al. 2002; RodriguezGarcia et al., 2012). Also, mixing different types of oils can moderate the properties of each oil and give the product more acceptability (Abdulkarim et al., 2010; Bakhtiary, 2014). Sowmya et al. (2009) found that, cake produced 
Zagazig J. Agric. Res., Vol. 46 No. (4) 2019

Table 2. Chemical composition of rusk containing different plant oils

\begin{tabular}{lccccc}
\hline Treatment & Moisture (\%) & Protein (\%) & Fat (\%) & Ash (\%) & Carbohydrates (\%) \\
\hline C & 2.49 & 7.9 & 22 & 0.55 & 67.06 \\
T1 & 2.31 & 8.4 & 22 & 0.64 & 66.65 \\
T2 & 2.14 & 8.6 & 28 & 0.81 & 60.45 \\
T3 & 2.58 & 9.6 & 26 & 1.30 & 60.52 \\
\hline
\end{tabular}

C : control rusk 30\%sunflower oil T1: Rusk containing 30\% sesame oil T2 : Rusk containing 30\% fenugreek oil T3 : Rusk containing a mixture of sunflower, sesame and fenugreek oils at ratio1:1:1

Table 3. Sensory evaluation of rusk containing different plant oils

\begin{tabular}{lcccccc}
\hline Treatment & $\begin{array}{c}\text { Appearance } \\
(\mathbf{9})\end{array}$ & $\begin{array}{c}\text { Colour } \\
(\mathbf{9})\end{array}$ & $\begin{array}{c}\text { Flavour } \\
(\mathbf{9})\end{array}$ & $\begin{array}{c}\text { Taste } \\
(\mathbf{9})\end{array}$ & $\begin{array}{c}\text { Texture } \\
(\mathbf{9})\end{array}$ & $\begin{array}{c}\text { Acceptability } \\
(\mathbf{9})\end{array}$ \\
\hline $\mathbf{C}$ & $8.44^{\mathrm{a}} \pm 0.59$ & $7.83^{\mathrm{a}} \pm 0.59$ & $8.33^{\mathrm{a}} \pm 1.07$ & $8.11^{\mathrm{a}} \pm 1.00$ & $8.50^{\mathrm{a}} \pm 0.76$ & $8.16^{\mathrm{a}} \pm 0.68$ \\
T1 & $7.61^{\mathrm{bc}} \pm 1.07$ & $7.72^{\mathrm{a}} \pm 0.87$ & $7.55^{\mathrm{b}} \pm 0.85$ & $7.78^{\mathrm{ab}} \pm 0.72$ & $8.11^{\mathrm{a}} \pm 1.02$ & $7.77^{\mathrm{ab}} \pm 0.80$ \\
T2 & $7.91^{\mathrm{abc}} \pm 0.86$ & $7.83^{\mathrm{a}} \pm 0.68$ & $7.71^{\mathrm{b}} \pm 0.57$ & $7.33^{\mathrm{bc}} \pm 0.84$ & $8.09^{\mathrm{a}} \pm 0.89$ & $7.71^{\mathrm{abc}} \pm 0.57$ \\
T3 & $8.11^{\mathrm{ab}} \pm 0.83$ & $7.91^{\mathrm{a}} \pm 0.73$ & $7.66^{\mathrm{b}} \pm 0.97$ & $7.54^{\mathrm{abc}} \pm 0.93$ & $8.00^{\mathrm{ab}} \pm 0.90$ & $7.66^{\mathrm{abc}} \pm 1.02$ \\
LSD & 0.60 & 0.51 & 0.59 & 0.58 & 0.62 & 0.55 \\
\hline
\end{tabular}

Values with different letters in the same column or row are significantly different at $(\mathrm{P}<0.05)$

$\mathrm{C}$ : Control rusk $30 \%$ sunflower oil T1: Rusk containing 30\% sesame oil

$\mathrm{T} 2$ : Rusk containing 30\% fenugreek T3 : Rusk containing a mixture of sunflower, sesame and fenugreek oils at ratio1:1:1

by replacement fat with $50 \%$ sesame oil gave cake better character ristics than the control cake with $100 \%$ fat. Kaur et al. (2012) found that, replaced oil with refined rice bran oil up to $50 \%$ level in the preparation of bread caused a significant improvement in baking quality of the product.

Results presented in Table 4 show that triglyceride, total cholesterol levels of the positive control group were significantly higher than that of the other experimental groups through the course of the experimental periods compared to the negative control group at zero time. Feeding hypercholesterolemic rats on rusk containing plant oils caused a significant $(\mathrm{P} \leq$ $0.05)$ decreased of triglycerides and total cholesterol compared to the positive control group at 3 weeks. By increasing the period of feeding hypercholesterolemic rats fed on rusk products caused a high significant $(\mathrm{P}<0.05)$ reduction in serum triglyceride and total cholesterol levels especially for G6 which fed on rusk containing mixture of sunflower, sesame and fenugreek oils compared to the positive control group for triglyceride and total cholesterol. Rats fed on high cholesterol diet had high level of LDL (104.67 mg/dl), VLDL (27.94 mg/dl) and low level of HDL $35.29 \mathrm{mg} / \mathrm{dl}$ compared to the negative control group at zero time. Feeding hypercholesterolemic rats on rusk containing plant oils caused a significant $(\mathrm{P} \leq 0.05)$ improvement in serum HDL levels for treated groups compared to the positive control group. Meanwhile, feeding hypercholesterolemic rats for 6 weeks caused a significant $(\mathrm{P} \leq 0.05)$ increase in HDL- cholesterol levels to be 52.94, 54.60, 54.03 and $57.08 \mathrm{mg} / \mathrm{dl}$ for $\mathrm{G} 3, \mathrm{G} 4, \mathrm{G} 5$ and G6, respectively compared to the positive control group $(34.51 \mathrm{mg} / \mathrm{dl})$ and a significant decrease in the levels of LDL and VLDL. While, feeding hypercholesterolemic rats on different rusk products caused a significant decrease in LDL/ HDL ratio compared to the positive control group. Moreover, G6 had the lowest LDL/HDL ratio $(0.85)$ and there were no significant differences between G4, G5 and G6 at the end of the experimental period. 
Table 4. Effect of rusk containing plant oils on serum lipid profile of hypercholesterolemic rats

\begin{tabular}{|c|c|c|c|c|c|c|c|}
\hline $\begin{array}{l}\text { Feeding } \\
\text { period } \\
\text { (week) }\end{array}$ & Group & $\begin{array}{c}\text { Triglyceride } \\
\text { (mg/dl) }\end{array}$ & $\begin{array}{c}\text { Total cholesterol } \\
(\mathrm{mg} / \mathrm{dl})\end{array}$ & $\begin{array}{c}\text { HDL } \\
(\mathrm{mg} / \mathrm{dl})\end{array}$ & $\begin{array}{l}\text { LDL } \\
\text { (mg/dl) }\end{array}$ & $\begin{array}{l}\text { VLDL } \\
\text { (mg/dl) }\end{array}$ & $\begin{array}{c}\text { LDL/HDL } \\
\text { Ratio } \\
\text { (mg/dl) }\end{array}$ \\
\hline \multirow{2}{*}{$\begin{array}{l}\text { Zero } \\
\text { time }\end{array}$} & G1(-Ve) & $105.60^{f} \pm 3.00$ & & $43.50^{\mathrm{e}} \pm 2.64$ & $77.22^{\mathrm{C}} \pm 1.88$ & $21.12^{f} \pm 0.60$ & $1.77^{\mathrm{c}} \pm 0.09$ \\
\hline & G2(+Ve) & $139.70^{\mathrm{b}} \pm 6.70$ & $167.91^{\mathrm{ab}} \pm 3.27$ & $35.29^{\mathrm{f}} \pm 0.67$ & $104.67^{\mathrm{ab}} \pm 5.05$ & $27.94^{\mathrm{b}} \pm 1.34$ & $2.96^{\mathrm{ab}} \pm 0.18$ \\
\hline \multirow[t]{6}{*}{3} & G1 & $118.27^{\mathrm{de}} \pm 8.97$ & $135.17^{\text {efgh }} \pm 9.21$ & $44.93^{\mathrm{e}} \pm 3.96$ & $72.58^{\mathrm{cd}} \pm 7.64$ & $23.65^{\mathrm{de}} \pm 1.79$ & $1.63^{\mathrm{cd}} \pm 0.32$ \\
\hline & G2 & $142.87^{\mathrm{b}} \pm 4.10$ & $165.31^{\mathrm{b}} \pm 5.36$ & $35.49^{\mathrm{f}} \pm 1.38$ & $101.24^{b} \pm 5.52$ & $28.57^{\mathrm{ab}} \pm 0.82$ & $2.86^{\mathrm{b}} \pm 0.24$ \\
\hline & G3 & $120.67^{\mathrm{cde}} \pm 4.93$ & $141.42^{\text {cde }} \pm 1.56$ & $49.44^{\mathrm{cd}} \pm 0.67$ & $67.85^{\mathrm{de}} \pm 2.19$ & $24.13^{\text {cde }} \pm 0.98$ & $1.37^{\mathrm{de}} \pm 0.06$ \\
\hline & G4 & $128.20^{\mathrm{c}} \pm 1.90$ & $138.49^{\text {cdef }} \pm 2.46$ & $51.01^{\mathrm{bcd}} \pm 1.93$ & $61.90^{\mathrm{ef}} \pm 1.71$ & $25.64^{\mathrm{c}} \pm 0.38$ & $1.21^{\mathrm{ef}} \pm 0.05$ \\
\hline & G5 & $127.47^{c} \pm 3.05$ & $136.02^{\operatorname{defg}} \pm 3.48$ & $50.57^{\mathrm{bcd}} \pm 0.19$ & $59.95^{\mathrm{fg}} \pm 4.15$ & $25.49^{c} \pm 0.61$ & $1.18^{\mathrm{ef}} \pm 0.08$ \\
\hline & G6 & $127.30^{c} \pm 2.70$ & $132.41^{\mathrm{fgh}} \pm 2.63$ & $52.34^{\mathrm{abc}} \pm 1.79$ & $54.81^{8 *} \pm 2.51$ & $25.46^{\mathrm{cd}} \pm 0.54$ & $1.04^{\mathrm{fg}} \pm 0.08$ \\
\hline \multirow[t]{6}{*}{6} & G1 & $121.70^{\text {cde }} \pm 5.90$ & $143.08^{\mathrm{c}} \pm 2.61$ & $47.00^{\mathrm{de}} \pm 6.31$ & $68.40^{\mathrm{d}} \pm 1.61$ & $24.34^{\mathrm{cde}} \pm 1.18$ & $1.47^{\mathrm{de}} \pm 0.19$ \\
\hline & G2 & $151.50^{\mathrm{a}} \pm 2.80$ & $173.85^{\mathrm{a}} \pm 3.64$ & $34.51^{\mathrm{f}} \pm 0.50$ & $109.04^{\mathrm{a}} \pm 3.62$ & $30.30^{\mathrm{a}} \pm 0.56$ & $3.16^{\mathrm{a}} \pm 0.12$ \\
\hline & G3 & $119.20^{\mathrm{de}} \pm 4.50$ & $136.37^{\mathrm{defg}} \pm 1.68$ & $52.94^{\mathrm{abc}} \pm 2.84$ & $59.50^{\mathrm{fgh}} \pm 5.19$ & $23.84^{\text {cde }} \pm 0.90$ & $1.12^{\mathrm{fg}} \pm 1.16$ \\
\hline & G4 & $124.67^{\mathrm{cd}} \pm 5.13$ & $134.37^{\mathrm{fgh}} \pm 5.04$ & $54.60^{\mathrm{ab}} \pm 1.39$ & $54.80^{\text {ghi }} \pm 4.87$ & $24.93^{\text {cde }} \pm 1.02$ & $1.00^{\mathrm{fg}} \pm 0.06$ \\
\hline & G5 & $117.33^{\mathrm{de}} \pm 4.60$ & $130.85^{\mathrm{gh}} \pm 1.12$ & $54.03^{\mathrm{ab}} \pm 2.67$ & $53.35^{\mathrm{hi}} \pm 2.92$ & $23.46^{\mathrm{e}} \pm 0.92$ & $0.99^{\mathrm{fg}} \pm 0.10$ \\
\hline & G6 & $116.83^{\mathrm{e}} \pm 3.15$ & $129.64^{\mathrm{h}} \pm 0.44$ & $57.08^{\mathrm{a}} \pm 1.57$ & $49.20^{i} \pm 1.60$ & $23.36^{\mathrm{e}} \pm 0.63$ & $0.85^{\mathrm{g}} \pm 0.05$ \\
\hline \multicolumn{2}{|c|}{ LSD } & 7.16 & 6.14 & 2.21 & 6.02 & 1.82 & 0.29 \\
\hline
\end{tabular}

Values with different letters in the same column or row are significantly different $(\mathrm{P}<0.05)$

G1(-Ve): negative control rat fed on basal diet. G2(+Ve): positive control rat fed on high cholesterol diet G3: hypercholesterolemic rats fed on 5\% rusk containing 30\% sunflower oil G4: hypercholesterolemic rats fed on 5\% rusk containing 30\% sesame oil G5: hypercholesterolemic rats fed on 5\% rusk containing 30\% fenugreek oil G6:hypercholesterolemic rats fed on 5\% rusk containing a mixture of sunflower, sesame and fenugreeks oils at ratio 1:1:1

The obtained results are in line with Hamden et al. (2011) who indicated that administration of omega-3 with fenugreek terpenenes caused a significant decrease in TG, TC, LDL and a significant increase in serum High-density lipoprotein (HDL) for diabetes rats which improve blood lipid profile. Boulbaroud et al. (2012) studied the effect of feeding ovariectomized (OVX) female wister rats on basal diet containing 10\% sesame oil caused a significant $(\mathrm{P} \leq 0.05)$ decrease in $\mathrm{TG}, \mathrm{TC}, \mathrm{LDL}$ and a significant increase in serum high-density lipoprotein (HDL) compared with the positive control. Also, Taha et al. (2014) stated that treatment hyperlipidemia rats (i.p injection of Triton WR1339 at does $200 \mathrm{mg} / \mathrm{Kg} /$ three times /week) by 5 and $10 \%$ of sesame oil (SSO) for 4 weeks and found that adding 5\% SSO has more significant effect than adding 10\% SSO on lipid profile. Moreover, Al-Ahdab (2015) studied the effect of sesame oil, Nigella sativa L oil and mixture of both at does $(5 \mathrm{mg} / \mathrm{kg}$ b.wt.) for 6 weeks on lipid profile of hypercholesterolemic rats. Revealed that oral administration of sesame oil, Nigella sativa $\mathrm{L}$ oil and their mixture caused a significant decreased in serum levels of TC, TG, low density lipoproteins cholesterol (LDLc), very low density lipoproteins cholesterol (VLDL-c) and a significant increase in serum high-density lipoprotein (HDL) compared with hypercholesterolemic rats.

The obtained results are matched with RM $\boldsymbol{e t}$ al. (2016) who studied the effects of vegetable oils such as sunflower oil, coconut oil, palm oil, olive oil and vanaspati on lipid profile. Vegetable oils caused increase in total cholesterol except sunflower oil. caused a significant decrease in serum TG, LDL, VLDL increase in serum Highdensity lipoprotein (HDL) Even though HDL level was observed in coconut oil treated groups. 
Also, Duavy et al. (2017) studied the effect of dietary supplementation with olive and sunflower oils by $12 \%$ on lipid profile of rats fed high cholesterol diet, $1 \%$. Sunflower oils caused a significant decrease in serum triglycerides (TG), total cholesterol (TC) low-density lipoprotein (LDL) and a significant increase in serum high-density lipoprotein (HDL). Meanwhile, group treated with olive oil caused a better improvement when compared with other treated groups by sunflower oil.

El-Masry et al. (2018) reported that fenugreek seed powder has hypolipidemic effect when added to diet by $5 \%$ with improving atherogenic index and caused a significant decrease in TG, TC, LDL,VLDL and a significant increase in serum High-density lipoprotein (HDL) for diabetes rats which improve blood lipid profile.

\section{Effect of Rusk Containing Plant Oils on Liver Functions}

Liver play an essential role in regulating plasma lipid level through LDL clearance and HDL recruitment, while lipid uptake must affect the hepatic fat composition and thus burden the liver function (Friis-liby et al., 2004). As shown in Table 5, the effect of administrating rusk on serum levels of total protein, ALT and AST enzymes activities. Hypercholesterolemic rats (G2) was characterized by a significant increase in total protein to be $7.10 \mathrm{~g} / \mathrm{dl}$ compared with normal group (G1) $6.77 \mathrm{~g} / \mathrm{dl}$ at zero time. There wasn't a significant differences between G4 and G6 compared with G2 after three weeks of feeding on rusk products. While, after six weeks of feeding there was a significant increase in total protein for G3, G4, G5 and G6 compared with hypercholesterolemic rats (G2). Also, G2 rats were characterized by a significant increase in ALT and AST enzymes activity to be 52.33 $\mathrm{U} / \mathrm{L}$ and $46.66 \mathrm{U} / \mathrm{L}$ compared to the negative control group to be $34.00 \mathrm{U} / \mathrm{L}$ at zero time. While, feeding hypercholesterolemic rats on rusk caused a significant decrease in ALT and AST enzymes activities for all treated groups G3, G4, G5 and G6 (25.00, 21.00, 18.33 and $18.33 \mathrm{U} / \mathrm{L})$ and $(19.33,19.00,19.33$ and 18.00 $\mathrm{U} / \mathrm{L})$ respectively compared to the positive control group (60.33 U/L) after 6 weeks of feeding. So, treatment hypercholesterolemic rats with rusk containing plant oils, caused a significant decrease in ALT and AST enzymes activities levels compared with the positive control group after 6 weeks of feeding.

Taha et al. (2014) showed that sesame oil caused a significant improvement in liver function which ALT and AST enzymes activity significantly decreased compared to the positive control group. Al-Ahdab (2015) found that sesame oil caused a significant decrease in ALT and AST levels compared with positive control group.

These results are in line with Periasamya $\boldsymbol{e t}$ al. (2014) who found that treated rats by sesame oil ( 1 and $2 \mathrm{ml} / \mathrm{kg}$ ) from $22^{\text {nd }}$ to $28^{\text {th }}$ day caused significant decrease in levels of serum AST and ALT. Mbarki et al. (2017) indicated that, feeding rats on basal diets supplemented with fenugreek seeds caused significant decrease in ALT, AST and total protein compared with control.

\section{Effect of Rusk Containing Plant Oils on Kidney Functions}

Results presented in Table 6 show that hypercholesterolemia rats group $(+\mathrm{Ve})$ was accompanied by a significant increase in kidney function parameters compared to the negative control group and treated groups. Meanwhile, feeding hypercholesterolemic rats on rusk containing plant oils caused a significant $(\mathrm{P} \leq$ 0.05 ) decrease in urea levels to be $32.08,30.49$, 31.34 and $29.52 \mathrm{mg} / \mathrm{dl}$ for G3, G4, G5 and G6, respectively compared to the positive control group $42.22 \mathrm{mg} / \mathrm{dl}$. Also, there was a significant decrease in creatinine levels for G3,G4, G5 and G6 to be $0.92,0.84,0.88$ and $0.81 \mathrm{mg} / \mathrm{dl}$ compared to the positive control group $(1.34 \mathrm{mg} / \mathrm{dl})$ at 3 weeks of feeding. By increasing the period of feeding hypercholesterolemic rats fed on rusk products caused a high significant $(\mathrm{P}<0.01)$ reduction in serum urea and creatinine levels especially for G6 which fed on rusk containing sunflower, sesame and fenugreek oils to be $28.33 \mathrm{mg} / \mathrm{dl}$ and $0.77 \mathrm{mg} / \mathrm{dl}$, respectively compared to the positive control group (41.98 $\mathrm{mg} / \mathrm{d})$ and $(1.30 \mathrm{mg} / \mathrm{dl})$ for urea and creatinine levels, respectively. 
Table 5. Effect of rusk containing plant oils on the liver functions of hypercholesterolemic rats

\begin{tabular}{|c|c|c|c|c|}
\hline $\begin{array}{c}\text { Feeding period } \\
\text { (week) }\end{array}$ & Group & $\begin{array}{l}\text { Total protein } \\
\text { (g/dl) }\end{array}$ & $\begin{array}{c}\text { ALT } \\
(\mathbf{U} / \mathbf{L})\end{array}$ & $\begin{array}{c}\text { AST } \\
(\mathbf{U} / \mathbf{L}) \\
\end{array}$ \\
\hline \multirow[t]{2}{*}{ Zero time } & $\mathrm{G} 1(-\mathrm{Ve})$ & $6.77^{\mathrm{de}} \pm 0.08$ & $34.00^{\text {cde }} \pm 5.00$ & $27.00^{\mathrm{c}} \pm 4.00$ \\
\hline & $\mathrm{G} 2(+\mathrm{Ve})$ & $7.10^{\mathrm{a}} \pm 0.01$ & $52.33^{b} \pm 4.50$ & $46.66^{\mathrm{ab}} \pm 5.50$ \\
\hline \multirow[t]{6}{*}{3} & G1 & $6.78^{\mathrm{cde}} \pm 0.19$ & $31.00^{\text {cdef }} \pm 7.21$ & $24.33^{\mathrm{cd}} \pm 2.30$ \\
\hline & G2 & $7.00^{\mathrm{ab}} \pm 0.11$ & $55.33^{\mathrm{ab}} \pm 2.88$ & $45.33^{b} \pm 12.09$ \\
\hline & G3 & $6.94^{\mathrm{abcd}} \pm 0.05$ & $35.66^{c} \pm 5.77$ & $24.33^{\mathrm{cd}} \pm 2.30$ \\
\hline & G4 & $7.06^{\mathrm{a}} \pm 0.14$ & $25.00^{\mathrm{fgh}} \pm 4.00$ & $23.00^{\mathrm{cd}} \pm 4.00$ \\
\hline & G5 & $6.80^{\text {cde }} \pm 0.08$ & $27.66^{\mathrm{defg}} \pm 2.30$ & $25.66^{\mathrm{cd}} \pm 2.30$ \\
\hline & G6 & $7.01^{\mathrm{ab}} \pm 0.01$ & $27.66^{\mathrm{defg}} \pm 2.30$ & $23.00^{\mathrm{cd}} \pm 0.00$ \\
\hline \multirow[t]{6}{*}{6} & G1 & $6.76^{\mathrm{de}} \pm 0.06$ & $26.33^{\mathrm{efg}} \pm 2.30$ & $27.00^{c} \pm 4.00$ \\
\hline & $\mathrm{G} 2$ & $6.72^{\mathrm{e}} \pm 0.06$ & $60.33^{\mathrm{a}} \pm 7.63$ & $54.33^{\mathrm{a}} \pm 4.04$ \\
\hline & G3 & $6.93^{\mathrm{abcd}} \pm 0.11$ & $25.00^{\mathrm{fgh}} \pm 4.00$ & $19.33^{\mathrm{cd}} \pm 3.51$ \\
\hline & G4 & $6.96^{\mathrm{abc}} \pm 0.20$ & $21.00^{\mathrm{gh}} \pm 4.00$ & $19.00^{\mathrm{cd}} \pm 0.00$ \\
\hline & G5 & $6.86^{\text {bcde }} \pm 0.05$ & $18.33^{\mathrm{h}} \pm 2.30$ & $19.33^{\mathrm{cd}} \pm 3.51$ \\
\hline & G6 & $7.04^{\mathrm{a}} \pm 0.06$ & $18.33^{\mathrm{h}} \pm 2.30$ & $18.00^{\mathrm{d}} \pm 1.73$ \\
\hline \multicolumn{2}{|c|}{ LSD } & 0.18 & 7.79 & 8.65 \\
\hline
\end{tabular}

Values with different letters in the same column or row are significantly different $(\mathrm{P}<0.05)$

G1(-Ve): negative control rat fed on basal diet. G2(+Ve): positive control rat fed on high cholesterol diet G3: hypercholesterolemic rats fed on 5\% rusk containing 30\% sunflower oil G4: hypercholesterolemic rats fed on 5\% rusk containing 30\% sesame oil G5: hypercholesterolemic rats fed on 5\% rusk containing 30\% fenugreek oil G6:hypercholesterolemic rats_fed on 5\% rusk containing a mixture of sunflower, sesame and fenugreeks oils at ratio 1:1:1

Table 6. Effect of rusk products fortified with plant oils on the kidney functions of hypercholesterolemic rats

\begin{tabular}{|c|c|c|c|}
\hline $\begin{array}{c}\text { Feeding period } \\
\text { (week) }\end{array}$ & Group & $\begin{array}{c}\text { Urea } \\
(\mathbf{m g} / \mathbf{d l}) \\
\end{array}$ & $\begin{array}{c}\text { Creatinine } \\
(\mathrm{mg} / \mathrm{dl})\end{array}$ \\
\hline \multirow[t]{2}{*}{ Zero time } & G1(-Ve) & $33.25^{\text {cde }} \pm 2.10$ & $1.03^{\mathrm{bc}} \pm 0.05$ \\
\hline & G2(+Ve) & $39.40^{\mathrm{b}} \pm 0.74$ & $1.41^{\mathrm{a}} \pm 0.09$ \\
\hline \multirow[t]{6}{*}{3} & G1 & $34.03^{\mathrm{cd}} \pm 1.13$ & $1.00^{\mathrm{bcd}} \pm 0.11$ \\
\hline & G2 & $42.22^{\mathrm{a}} \pm 1.32$ & $1.34^{\mathrm{a}} \pm 0.12$ \\
\hline & G3 & $32.08^{\mathrm{def}} \pm 1.41$ & $0.92^{\text {cde }} \pm 0.05$ \\
\hline & G4 & $30.49^{\mathrm{fgh}} \pm 0.66$ & $0.84^{\mathrm{ef}} \pm 0.04$ \\
\hline & G5 & $31.34^{\mathrm{efg}} \pm 0.39$ & $0.88^{\mathrm{def}} \pm 0.09$ \\
\hline & G6 & $29.52^{\mathrm{gh}} \pm 0.45$ & $0.81^{\mathrm{ef}} \pm 0.03$ \\
\hline \multirow[t]{6}{*}{6} & G1 & $35.60^{c} \pm 0.44$ & $1.06^{\mathrm{b}} \pm 0.13$ \\
\hline & G2 & $41.98^{\mathrm{ab}} \pm 2.63$ & $1.30^{\mathrm{a}} \pm 0.10$ \\
\hline & G3 & $29.93^{\mathrm{fgh}} \pm 0.32$ & $0.88^{\mathrm{def}} \pm 0.06$ \\
\hline & G4 & $29.17^{\mathrm{gh}} \pm 0.93$ & $0.80^{\mathrm{ef}} \pm 0.01$ \\
\hline & G5 & $29.75^{\mathrm{fgh}} \pm 0.87$ & $0.80^{\mathrm{ef}} \pm 0.04$ \\
\hline & G6 & $28.33^{\mathrm{h}} \pm 0.57$ & $0.77^{\mathrm{f}} \pm 0.05$ \\
\hline \multicolumn{2}{|c|}{ LSD } & 2.32 & 0.12 \\
\hline
\end{tabular}

Values with different letters in the same column or row are significantly different $(\mathrm{P}<0.05)$

G1(-Ve): negative control rat fed on basal diet. G2(+Ve): positive control rat fed on high cholesterol diet G3: hypercholesterolemic rats fed on 5\% rusk containing 30\% sunflower oil G4: hypercholesterolemic rats fed on 5\% rusk containing 30\% sesame oil G5: hypercholesterolemic rats fed on 5\% rusk containing 30\% fenugreek oil G6:hypercholesterolemic rats fed on 5\% containing a mixture of sunflower, sesame and fenugreeks oils at ratio 1:1:1. 
Hamden et al. (2010) stated that fenugreek oil caused a significant decrease in urea and creatinine levels in treated groups compared with the positive control group. Also, Periasamy et al. (2010) and Mbarki et al. (2017) showed that sesame oil may enhance the ability of the kidney to remove these waste products from the blood by decreasing the levels of urea and creatinine.

\section{Histopathological examination}

Histopathological of the rat's liver tissues are shown in Photos 1, 2, 3, 4, 5 and 6.

It is observed in Photo 2 that liver sections showed moderate congestion of the portal blood vessels with mild biliary proliferation, lymphocytosis and round cells infiltration. The latter were seen aggregated interstitially most of the hepatocytes were apparently normal however a few cells showed cloudy swelling ,hydropic degeneration and fatty changes. Photo 3 shows that liver sections showed congestion of portal blood vessels, biliary proliferation and focal interstitial round cells aggregations. Photo. 4 shows that liver sections showed mild congestion of the portal blood vessels, dilatation of the lymphatic and mild biliary proliferation. Moderate number of hepatocytes showed hydropic degeenrtion. Photo 5 shows that liver sections had congestion of hepatic blood vessels with apoptotic changes of some hepatocytes.

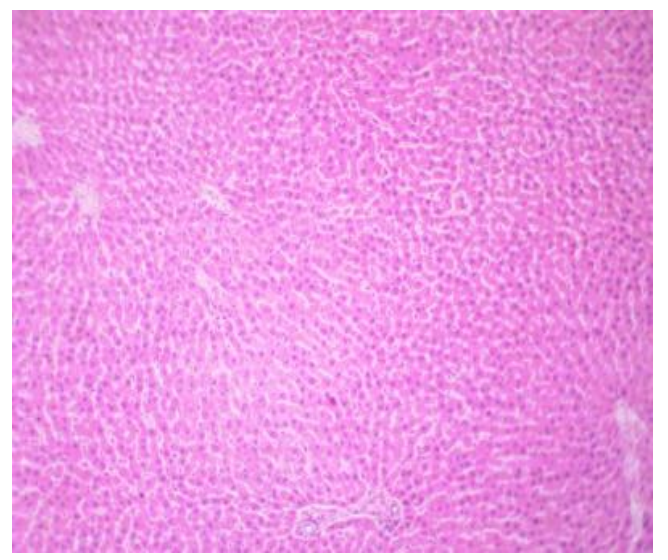

Photo. 1. G1(-Ve): Liver tissue of negative control group $H$ and $E(X$ 400)
Examined sections from liver showed mild congestion of the portal blood vessels, biliary proliferation and round cells infiltration which aggregated interstitially in addition to hydropic degeneration of some hepatocytes (Photo 6). Consumption of sesame oil containing sesamol, sesamin and other lignans had anti-inflammatory effects (Chavali and Forse, 1999; Chavali $\boldsymbol{e t}$ al., 2001). Which, sesamol attenuated the recruitment of inflammatory cells, mast cells, CD68 (+) Kupffer cells, and neutrophils in liver injury (Periasamy et al., 2011). Sesamol can reduce the recruitment of inflammatory cells by production of cytokine. In addition, sesamol can improving activation during systemic inflammation by reducing the transcription of pro-inflammatory cytokines that induces inflammation (Hsu $\boldsymbol{e t}$ al., 2006; Hsu et al., 2013). Sesame oil significantly decreasing levels of leptin. Leptin have an adipocyte-derived cytokine, the main regulator of hepatic triglyceride content (Fishman et al., 2007). So, these results are in agreement with Periasamya et al. (2014) who revealed that sesame oil caused a significant protection against fibrotic collagen. Also, sesame oil had protects against steatohepatitic fibrosis by decreasing inflammatory cytokines, oxidative stress, , leptin and TGF- $\beta 1$. Also, sesame oil decreased proinflammatory cytokines that might attenuate the hepatic inflammation, steatosis, and eventually fibrosis.

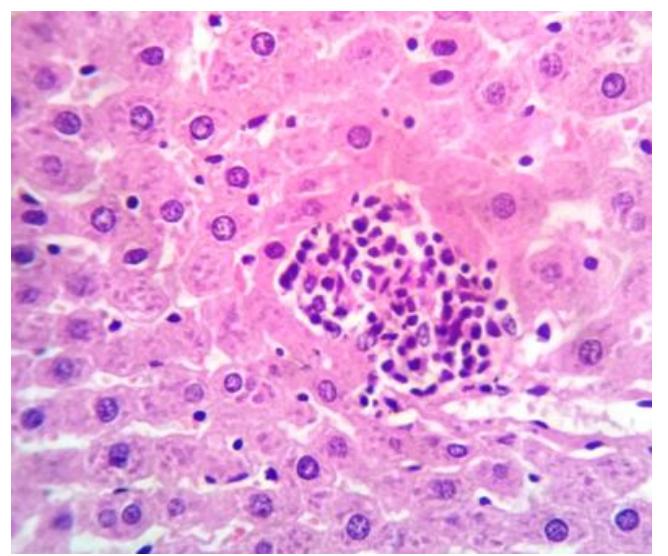

Photo.2. G2 (+Ve): Liver tissue of positive control group $H$ and $E$ (X 400) 
Ismail, et al.

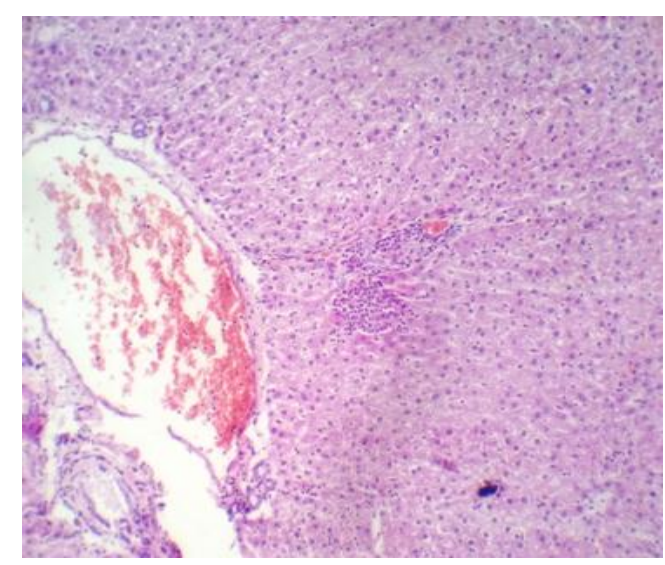

Photo 3. G3: Liver tissue of hypercholesterolemic rats fed on rusk containing $30 \%$ sunflower oil $H$ and $E$ (X 400)

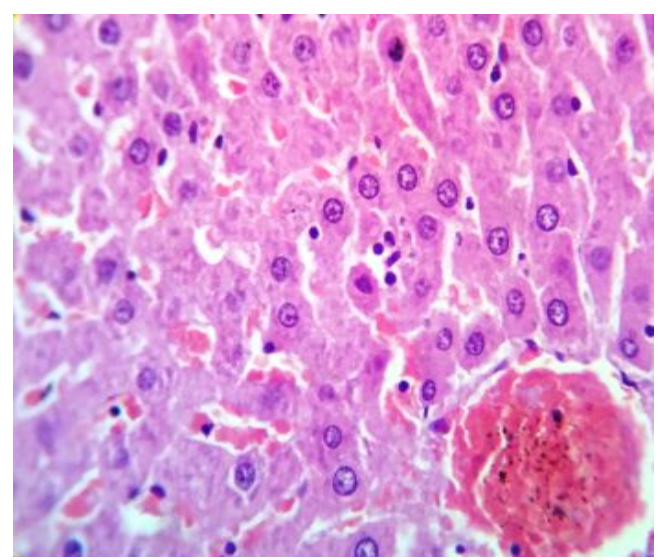

Photo 5. G4: Liver tissue of hypercholesterolemic rats fed on rusk containing $30 \%$ fenugreek oil $H$ and $E$ (X 400)

Mbarki et al. (2017) found that, feeding rats on diets supplemented by fenugreek seeds is significantly effective in protecting the liver.

\section{Conclusion}

The present study has demonstrated the potency of using plant oils as sunflower, sesame and fenugreek oils and their mixture as functional ingredients in bakery products (rusk) which caused significant improvement in lipid profile, liver and kidney functions for hypercholesterolemic rats. These findings provide a basis for the use of these plant oils and their mixture. Further, research must be done on the future on new plants oils with the high content of different bioactive compounds and

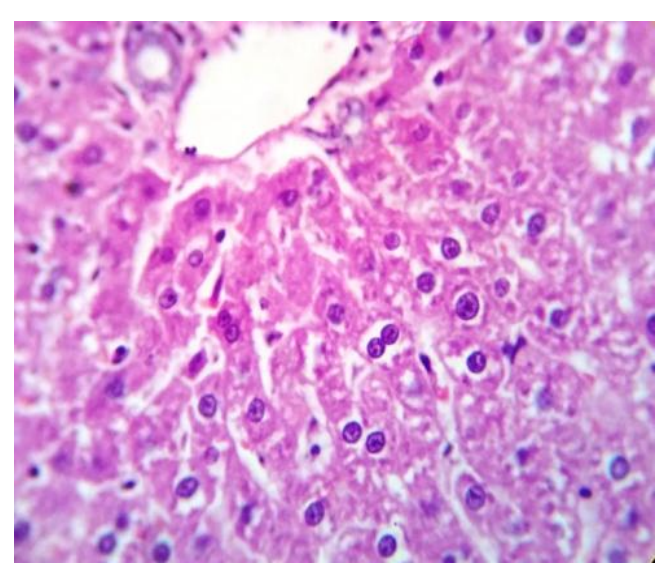

Photo 4. G4: Liver tissue of hypercholesterolemic rats fed on rusk containing $30 \%$ sesame oil $H$ and $E$ ( $X$ 400)

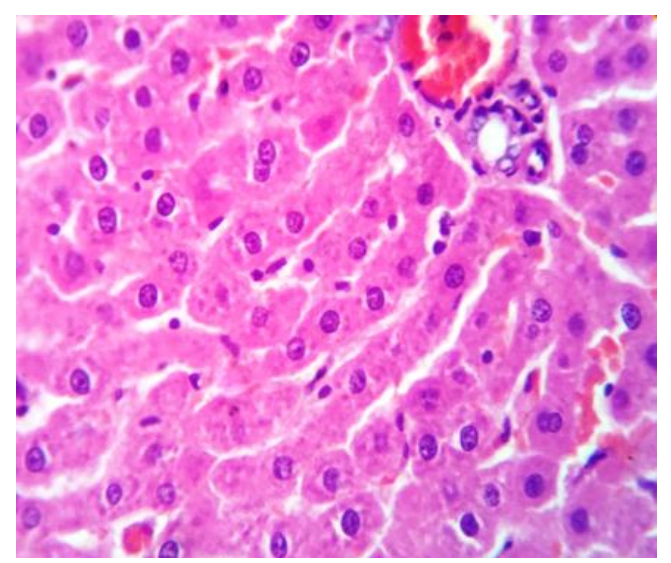

Photo 6. G6: Liver tissue of hypercholesterolemic rats fed on rusk which containing a mixture of sunflower, sesame, and fenugreek oils1:1:1 $\mathrm{H}$ and $\mathrm{E}$ (X 400)

extended their applications in human diets, industrial instead of margarine and animal fats which may have induced health hazards and side effects for the human being.

\section{REFRENCES}

AACC (2002). Approved Methods of the American Association of Cereal chemists. Published by the Ame. Ass. Cereal Chem. Inc. St. Paul., Minnesota, USA.

Abdulkarim, S.M., M.W. Myat and H.M. Ghazali (2010). Sensory and physicochemical qualities of palm olein and sesame seed oil blends during frying of banana chips. J. Agric. Sci., 2: 18-29. 
Ahmad, S., S. Yousuf, T. Ishrat, M.B. Khan, K. Bhatia, I.S. Fazli, J.S. Khan, N.H. Ansari and F. Islam (2006). Effect of dietary sesame oil as antioxidant on brain hippocampus of rat in focal cerebral ischemia. Life Sci., 79 : 19211928.

Ain (1993). American Institute of Nutrition. Purified diet for laboratory rodent, Final report., J. Nutr., 123, 1939-1951. and $O$. compactum Benth. J. Essential oil Res., 8 (6): 657-664.

Akbari, S., N.H. Abdurahman, R.M. Yunus, O.R. Alara and O.O. Abayomi (2018). Extraction, characterization and antioxidant activity of fenugreek (Trigonella- foenum graecum) seed oil. Materials Sci. Energy Technol., 2589-2991 (18): 30096-X.

Al-Ahdab, M.A. (2015). Effect of sesame oil, Nigella sativa $\mathrm{L}$ oil and their mixtures on lipid profile and liver enzymes in hypercholesterolemic rats. J. Am. Sci., 11 (12): 66-73.

Ali, M.A., M.A. Sayeed, M.S. Alam, M.S. Yeasmin, A.M. Khan and I.I. Muhamad (2012). Characteristics of oils and nutrient contents of Nigella sativa Linn. and Trigonella foenum-graecum seeds. Bull. Chem. Soc. Ethiop., 26 : 55-64.

Almasodi, A.G.S. (2018). Production and evaluation of some bakery products containing ginger powder. J. Food and Nutr. Res., 6 (4): 205-215.

AOAC (2005). Official Methods of Analysis of Association of Official Analytical Chemists. Published by the AOAC international $18^{\text {th }}$ Ed. Washington, D.C.

Arshad, M. and M. Amjad (2012). Medicinal use of sunflower oil and present status of sunflower in Pakistan. Sci. Technol. Develop., 31 (2): 99-106.

Bahmani, M., H. Shirzad, M. Mirhosseini, A. Mesripour and M. Rafieian-Kopaei (2016). A review on ethnobotanical and therapeutic uses of fenugreek (Trigonella foenumgraceum L), J. Evidence-Based Complement. Altern. Med., 21: 53-62.
Bakhtiary, D. (2014). Sensory qualities of sesame oil, palm olein and the blend of them during frying of potato chips. Technical J. Eng. and Appl. Sci., 4 : 48-52.

Boulbaroud, S., A. El-Hessni1, F-Z. Azzaoui and A. Mesfioui (2012). Sesame seed oil and flaxseed oil affect plasma lipid levels and biomarkers of bone metabolism in ovariectomized Wistar rats. Biol. and Med., 4 (3): 102-110.

Budryn, G., E. Nebesny, D. Zyzelewicz and J. Oracz (2014). Properties of model systems of sunflower oil and green coffee extract after heat treatment and storage. LWT - Food Sci. and Technol., $59:$ 467-478 .

Burtis, A. (1999). Tietz Textbook of Clinical Chemistry, $3^{\text {rd }}$ Ed. AACC.

Chavali, S.R. and R.A. Forse (1999). Decreased production of interleukin- 6 and prostaglandin E2 associated with inhibition of D-5 desaturation of $\mathrm{v} 6$ fatty acids in mice fed safflower oil diets supplemented with sesamol. Prostaglandins Leukot Essent Fatty Acids., 61: 347-52.

Chavali, S.R., T. Utsunomiya and R.A. Forse (2001). Increased survival after cecal ligation and puncture in mice consuming diets enriched with sesame seed oil. Crit Care Med., 29 : 140-3.

Duavy, S.M.P., G.J.T. Salazar, G.O. Leite, A. Ecker and N.V. Barbosa (2017). Effect of dietary supplementation with olive and sunflower oils on lipid profile and liver histology in rats fed high cholesterol diet. Asian Pacific J. Tropical Med., 10 (6): 539 543.

Egan, H., R.S. Kirk and R. Sawyer (1981) Pearson's Chemical Analysis of Foods, $8^{\text {th }}$ ed., Churchill Livingstone: Edinburgh., 11: 519-536.

El Bairi, K., M. Ouzir, N. Agnieszka and L. Khalki (2017). Anticancer potential of Trigonella foenum graecum: Cellular and molecular targets, Biomed. Pharmacother, 90: 479-491.

El-Masry, H., N. Taha, A. Mandour, M. Lebda and A. Hashem (2018). Effect of Fenugreek 
(Trigonella foenum graecum) on lipid profile and sexual hormones in induced hyperlipidemic rats. AJVS., 58 (1): 186-190.

Erkkilä, A., V.D. de Mello, U. Risérus and D.E. Laaksonen (2008). Dietary fatty acids and cardiovascular disease: An Epidemiological Approach. Prog. Lipid Res., 47: 172-187.

Filipovic, V., J. Filipovic, J. Gvozdenovic and D. Novakovic (2012). Packaging material characteristics contributing to shelf-life of rusk. Romanian Biotechnol. Lett., 17 (2): 7125 - 7135 .

Fishman, S., R.H. Muzumdar, G. Atzmon, X. Ma, X. Yang and F.H. Einstein (2007). Resistance to leptin action is the major determinant of hepatic triglyceride accumulation In vivo. FASEB J., 21: 53-60.

Fliiopovic, N., G. Kaludjerski, K. Vranac, Z. Vrbski and N. Sstancovic (1991). Influence of pan release grease on the Rusk shelf-life, Cereal-Bread., 18: 13-17.

Friedwald, W.T., R.I. Leve and D.S. Fredrickson (1972). Estimation of the concentration of low-density lipoprotein separated by three different methods. Clin. Chem., 18: 499-502.

Friis-liby, L., F. Aldenborg, P. Jerlstad, K. Rundstrom and E. Btornsson (2004). High prevalence of metabolic complications in patients with non-alcoholic fatty liver disease . Scanin avian. J. Gastroenterol., 39: 864869.

Gupta, M., A.S. Bawa and A.D. Semwal, (2011). Effect of barley flour blending on functional, baking and organoleptic characteristics of high-fiber rusks. J. Food Proc. and Preservation, 35: 46-63.

Gustafsson, I.B., B. Vessby, M. Ohrvall and M. Nydahl (1994). A diet rich in monounsaturated rapeseed oil reduces the lipoprotein cholesterol concentration and increases the relative content of n-3 fatty acids in serum in hyperlipidemic subjects. Ame. J. Clin. Nutr., 59: 667-74.

Hamden, K., H. Keskes, S. Belhaj, K. Mnafgui, A. Feki and N. Allouche (2011). Inhibitory potential of omega-3 fatty and fenugreek essential oil on key enzymes of carbohydrate-digestion and hypertension in diabetes rats. Lipids in Health and Disease, $10,226$.

Hamden, K., H. Masmoudi, S. Carreau and A. Elfeki (2010). Immunomodulatory, $\beta$-cell, and neuroprotective actions of fenugreek oil from alloxan-induced diabetes. Immunopharmacol. and Immunotoxicol., 32(3): 437-445.

Han, H., F. Qiu, H. Zhao, H. Tang, X. Li and D. Shi (2018). Dietary flaxseed oil improved western-type diet-induced atherosclerosis in apolipoprotein-E knockout mice. J. Functional Foods, 40: 417- 425.

Hartman, L. and R. C. A. Lago (1973). Rapid preparation of fatty acids methyle esters from lipids. Lab. Pract., 22: 475.

Hedjazi, L., S. Guessasma, V.G. Della and N. Benseddiq (2011) How cracks propagate in a vitreous dense biopolymer material. Eng. Fract Mech., 78 (6): 1328-1340.

Hsu, D.Z., K.T. Chen, Y.H. Li, Y.C. Chuang, and M.Y. Liu (2006). Sesamol delays mortality and attenuates hepatic injury after cecal ligation and puncture in rats: role of oxidative stress. Shock., 25: 528-32.

Hsu, D.Z., Y.W. Chen, P.Y. Chu, S. Periasamy and M.Y. Liu (2013). Protective effect of 3,4- methylenedioxyphenol (sesamol) on stress-related mucosal disease in rats. Biomed. Res. Int., 481827,8.

Ingale, S. and S.K. Shrivastava (2011). Chemical studies of new varieties of sunflower (Helianthus annuus) LSF-11 and LSF-8 seeds. Agric. Biol. J. N. Am., 2 (8): 1171-1181.

Jiang, J.X., L.W. Zhu, W.M. Zhang and R.C. Sun (2007). Characterization of galactomannan gum from fenugreek (Trigonella foenumgraecum) seeds and its rheological properties, Int. J. Polym. Mater. Polym. Biomater, 56: 1145-1154.

Kaur, A., V. Jassal, S.S. Thind and P. Aggarwal (2012). Rice bran oil an alternate bakery shortening . J Food Sci. Technol., 49 (1): 110 -114 . 
Kochhar, S.P. (2000). Sesame oil, A powerful antioxidant. Lipid Technol. Newsletter., 6, 35-39.

Libby, P. (2008). The pathogenesis, prevention and treatment of atherosclerosis. Harrison's Principles of Int. Med. II, pp 1501-1509, New York, McGraw Hill.

Mbarki, S., H. Alimib, H. Bouzennaa, A. Elfekia and N. Hfaiedha (2017). Phytochemical study and protective effect of Trigonella foenum graecum (Fenugreek seeds) against carbon tetrachloride-induced toxicity in liver and kidney of male rat. Biomedicine and Pharmacotherapy, 88: 19-26.

Meilgard, M., G.V. Civille and B.T. Carr (1991). Sensory Evaluation Techniques. $2^{\text {nd }}$ Ed. Florida, USA: CRC Press, 354.

Mijena, R.B. (2017). Optimization of sesame roasting parameters and level of ingredients for sesame fat spread production. Int. J. Nutr. and Food Sci., 6(4) : 149-157.

Mišurcová, L., J. VávraAmbrožová and D. Samek (2011). Seaweed lipids as nutraceuticals. Adv. Food Nutr. Res., 64: 339-355.

Mobraten, K., T.M. Haug, C.R. Kleiveland and T. Lea (2013). Omega-3 and omega-6 PUFAs induce the same GPR120-mediated signaling events, but with different kinetics and intensity in Caco-2 cells. Lipids Health Dis., 12: 101-107.

Naidu, M.M., B.N. Shyamala, J.P. Naik, G. Sulochanamma and P. Srinivas (2011). Chemical composition and antioxidant activity of the husk and endosperm of fenugreek seeds. LWT- Food Sci. and Technol., 44: 451- 456.

Neylon, A., C. Canniffe, S. Anand, C. Kreatsoulas, G.J. Blake and D. Sugrue (2013). A global perspective on psychosocial risk factors for cardiovascular disease. Prog Cardiovasc Dis., 55 (6): 574-81.

Olaoye, O.A. and A.A. Onilude (2008). Microbiological, proximate analysis and sensory evaluation of baked products from blends of wheat bread flours. Afr. J. Food Agric., Nut. Dev., 8 (2): 192-203.
Orsavova, J., L. Misurcova, J.V. Ambrozova, R. Vicha and J. Mlcek (2015). Fatty acids composition of vegetable oils and its contribution to dietary energy intake and dependence of cardiovascular mortality on dietary intake of fatty acids. Int. J. Mol. Sci., 16: 12871-12890.

Periasamy, S., C.T. Liu, D.Z. Hsu and M.Y. Liu (2010). Sesame oil accelerates kidney healing following gentamicin-induced kidney injury in rats. Ame. J. Nephrol., 32: 383-392.

Periasamy, S., D.Z. Hsu, S.Y. Chen, S.S. Yang, V.R. Chandrasekaran and M.Y. Liu (2011). Therapeutic sesamol attenuates monocrotalineinduced sinusoidal obstruction syndrome in rats by inhibiting matrix metalloproteinase- 9 . Cell Biochem Biophys., 61: 327-336.

Periasamya, S., S. Chienb, P. Changa, D. Hsua and M. Liua (2014). Sesame oil mitigates nutritional steatohepatitis via attenuation of oxidative stress and inflammation: a tale of two-hit hypothesis. J. Nutr. Bioch., $25: 232$ 240.

Poster, L. (1991). Laboratory Methods for Sensory Analysis of Food. Ottawa Agric. Canada, Phistol., 210.

RM, P., U. D'Souza, S. Bhat and K.M.R. Bhat (2016). Effect of vegetable oils on the lipid profile and antioxidant status in Wistar rats: A comparative study. J. Int. Med. and Denti., 3 (2): 109-114.

Rodriguez-Garcia, J., L. Laguna, A. Puig, A. Salvador and I. Hernando (2012). Effect of fat replacement by inulin on textural and structural properties of short dough biscuits. J. Food Sci., 77 (2): C189 - C197.

Salas, J.J., M.A. Bootello, E. Martenez-Force and R. Garcés (2011). Production of stearaterich butters by solvent fractionation of high stearic-high oleic sunflower oil. Food Chem., 124: 450-458.

Shalaby, H.S., G.M. El-Araby and A.E. Awad (2016). Assessment of antidiabetic activity of (Physalis pubescens L.) in Rusk. Zagazig J. Agric. Res., 43 : 6B.

Shi, X., T. Miyakawa, A. Nakamura, F. Hou, M. Hibi, J. Ogawa, Y. Kwon and M. Tanokura 
(2017). Engineering a short-chain dehydrogenase / reductase for the stereoselective production of $(2 \mathrm{~S}, 3 \mathrm{R}, 4 \mathrm{~S})$-4-hydroxyisoleucine with three asymmetric centers, Sci. Rep., 7: 1-13.

Simopoulos, A.P. (2002). The importance of the ratio of omega-6/ omega-3 essential fatty acids. Biomed Pharmacother., 56, 365-379

Simopoulos, A.P. (2011). Evolutionary aspects of diet: the omega-6/ omega- 3 ratio and the brain. Mol Neurobiol., 44, 203-215.

Sowmya, M., T. Jeyarani, R. Jyotsna and D. Indrani (2009). Effect of replacement of fat with sesame oil and additives on rheological, microstructural, quality characteristics and fatty acid profile of cakes. Food Hydrocolloids, 23: $1827-1836$.

Steel, R.G.D. and J.H. Torrie (1980). Principles and Procedures of Statistics. McGraw., New York.

Strǿmgaard, K. and K. Nakanishi (2004). Chemistry and biology of terpene trilactones from Ginkgo biloba. Angew. Chem. Int. Ed. Engl., 19: 1640-58.

Subhapriya, S. and P. Gomathipriya (2018). Green synthesis of titanium dioxide (TiO2) nanoparticles by Trigonella foenum-graecum extract and its antimicrobial properties, Microb. Pathog., 116: 215-220.

Suvarna, K.S., L. Christopher and J.D. Bancroft (2013). Bancroft's Theory and Practice of Histological Techniques, $7^{\text {th }} \mathrm{Ed}$.

Taha, N.M., A.A. Mandour, M.K. Mohamed and R. T. Emarha (2014). Effect of sesame oil on serum and liver lipid profile in hyperlipidemic rats. Alex. J. Vet. Sci., 43: $18-25$.

Tavakoly, R., M.R. Maracy, M. Karimifar and M.H. Entezari (2018). Does fenugreek
(Trigonella foenum-graecum) seed improve inflammation, and oxidative stress in patients with type 2 diabetes mellitus? A parallel group randomized clinical trial, Eur. J. Integr. Med., 18: 13-17.

Tietz, N.W. (1995). Clinical Guide to Laboratory Tests, $3^{\text {rd }}$ Ed. AACC.

Tigrine-Kordjani, N., B.Y. Meklati and F. Chemat (2011). Contribution of microwave accelerated distillation in the extraction of the essential oil of Zygophyllum album L. Phytochem Anal., 22 (1): 1-9.

WHO (2008) World Health Organisation. World health statistics. Geneva: World Health Organisation.

Yokoyama, H., K. Kawai, M. Ohishi and H. Sone (2008). Japan Diabetes Data Management Study Group. Familial predisposition to cardiovascular risk and disease contributes to cardiovascular risk and disease interacting with other cardiovascular risk factors in diabetes: implication for common soil (JDDM 14). Atherosclerosis., 201 (2): 332-8.

Young, D.S. (2001). Effects of Disease on Clinical Lab. Tests, $4^{\text {th }}$ Ed. AACC.

Zebib, H., G. Bultosa and S. Abera (2015). Physico-Chemical Properties of Sesame (Sesamum indicum L.) Varieties Grown in Northern Area, Ethiopia. Agric. Sci., 6: 238246.

Ziwar, J.B. (2010). Estimation of Lipid Composition in Fenugreek Seed by GC/MS. Tikrit J. Pure Sci., 15: 15-20.

Zoulias, E.I., V. Oreopoulou and C. Tzia (2002). Textural properties of low fat cookies containing carbohydrate- or protein-based fat replacers. J. Food Eng., 55 (4): 337-342. 
تأثير البقسماط المحتوي على بعض الزيوت النباتية على الفئران المصابة بأرتفاع مستوي الكولستيرول

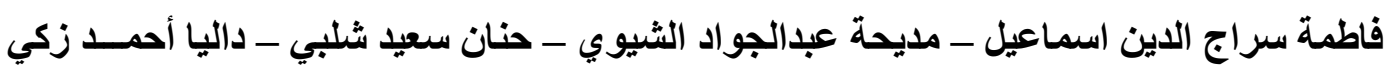

$$
\begin{aligned}
& \text { قسم علوم الأغذية (شعبة اقتصاد منزلي ريفي) - كلية الزراعة - جامعة الزقازيق - مصر الفيان }
\end{aligned}
$$

تستخدم بعض الزيوت النباتية كزيت دوار الثمس، زيت السمسم وزيت الحلبة في عمليات التصنيع الغذائى وخاصة

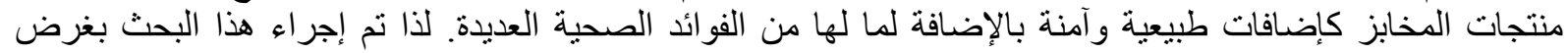

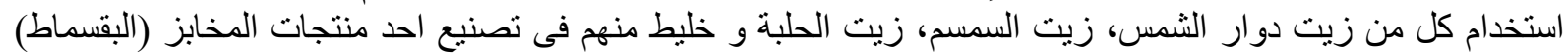

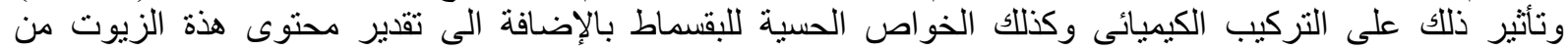

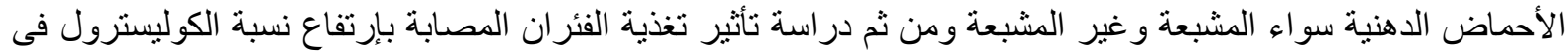

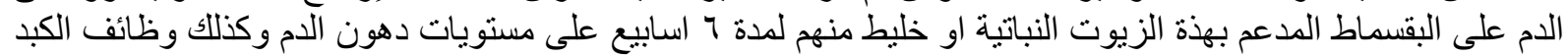

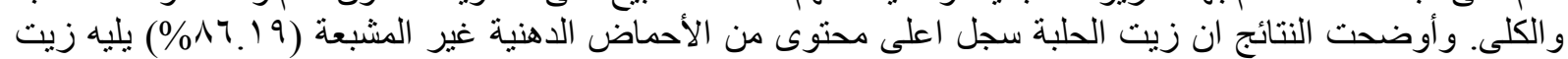

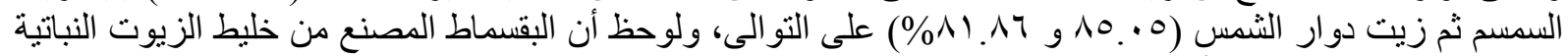

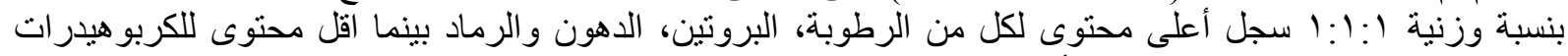

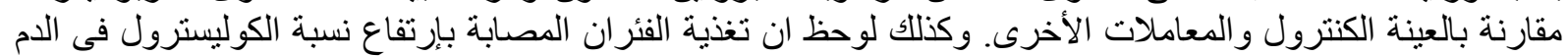

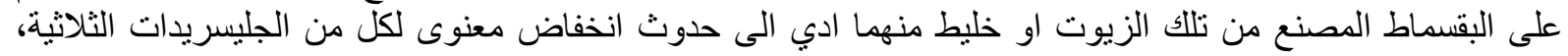

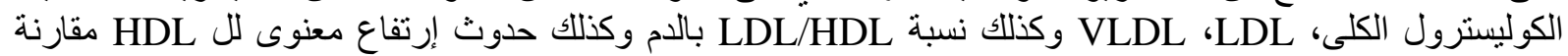

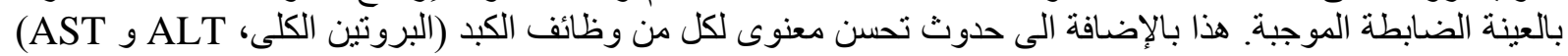

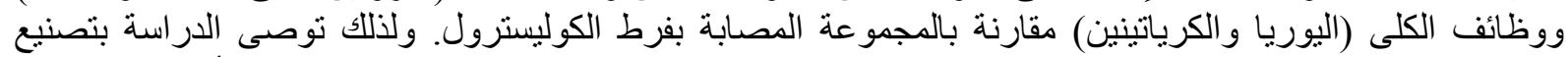

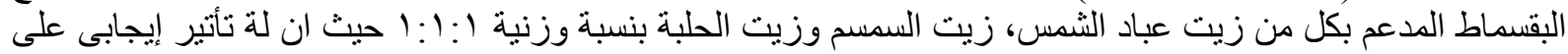
خفض مستويات الكوليسترول بالام. 